\title{
Implementing REDD+ (Reducing Emissions from Deforestation and Degradation): evidence on governance, evaluation and impacts from the REDD-ALERT project
}

\author{
Robin B. Matthews • Meine van Noordwijk • \\ Eric Lambin • Patrick Meyfroidt • Joyeeta Gupta • \\ Louis Verchot • Kristell Hergoualc'h • Edzo Veldkamp
}

Received: 2 March 2014 / Accepted: 15 May 2014 / Published online: 9 June 2014

(C) The Author(s) 2014. This article is published with open access at Springerlink.com

\begin{abstract}
The REDD-ALERT (Reducing Emissions from Deforestation and Degradation from Alternative Land Uses in the Rainforests of the Tropics) project started in 2009 and finished in 2012, and had the aim of evaluating mechanisms that translate international-level agreements into instruments that would help change the behaviour of land users while minimising adverse repercussions on their livelihoods. Findings showed that some developing tropical countries have recently been through a forest transition, thus shifting from declining to
\end{abstract}

R. B. Matthews $(\bowtie)$

James Hutton Institute, Craigiebuckler, Aberdeen AB15 8QH, UK

e-mail: robin.matthews@hutton.ac.uk

M. van Noordwijk

World Agroforestry Centre, Jl. Gunung Batu No. 5, P O Box 161, Bogor 16001, Indonesia

E. Lambin · P. Meyfroidt

Earth and Life Institute, Georges Lemâtre Center for Earth and Climate Research, Université Catholique de Louvain, Louvain-la-Neuve 1348, Belgium

P. Meyfroidt

F.R.S. - FNRS, Brussels, Belgium

J. Gupta

Global South Governance and Inclusive Development (GID), Amsterdam Institute for Social Science

Research, University of Amsterdam, Amsterdam, The Netherlands

J. Gupta

UNESCO-IHE Institute for Water Education, Delft, The Netherlands

L. Verchot $\cdot$ K. Hergoualc'h

Centre for International Forestry Research, P.O. Box 0113, BOCBD, Bogor 16000, Indonesia

E. Veldkamp

Soil Science of Tropical \& Subtropical Ecosystems, Büsgen Institute, Georg-August University of

Göttingen, Büsgenweg 2, 37077 Göttingen, Germany 
expanding forests at a national scale. However, in most of these (e.g. Vietnam), a significant part of the recent increase in national forest cover is associated with an increase in importation of food and timber products from abroad, representing leakage of carbon stocks across international borders. Avoiding deforestation and restoring forests will require a mixture of regulatory approaches, emerging market-based instruments, suasive options, and hybrid management measures. Policy analysis and modelling work showed the high degree of complexity at local levels and highlighted the need to take this heterogeneity into account - it is unlikely that there will be a one size fits all approach to make Reducing Emissions from Deforestation and Degradation (REDD+) work. Significant progress was made in the quantification of carbon and greenhouse gas (GHG) fluxes following land-use change in the tropics, contributing to narrower confidence intervals on peat-based emissions and their reporting standards. There are indications that there is only a short and relatively small window of opportunity of making REDD+ work - these included the fact that forest-related emissions as a fraction of total global GHG emissions have been decreasing over time due to the increase in fossil fuel emissions, and that the cost efficiency of REDD+ may be much less than originally thought due to the need to factor in safeguard costs, transaction costs and monitoring costs. Nevertheless, REDD+ has raised global awareness of the world's forests and the factors affecting them, and future developments should contribute to the emergence of new landscape-based approaches to protecting a wider range of ecosystem services.

Keywords Reducing Emissions from Deforestation and Degradation - REDD $+\cdot$ Indonesia $\cdot$ Vietnam · Cameroon · Peru · Peatlands · Carbon stocks · Greenhouse gases · GHGs

\section{Introduction}

Conceived at the initial spurt of international interest in how new economic instruments could contribute to a reduction of carbon emissions from tropical forests, and funded under the European Union Framework 7 Programme, the aim of the Reducing Emissions from Deforestation and Degradation from Alternative Land Uses in the Rainforests of the Tropics (REDD-ALERT) project (www.redd-alert.eu) was to make a contribution to the evaluation of mechanisms that translate international climate agreements into instruments that would help change the behaviour of the people directly involved in clearing trees while minimising adverse repercussions on their livelihoods. Partners included the James Hutton Institute, the World Agroforestry Centre (ICRAF), the Université Catholique de Louvain, Vrije Universiteit Amsterdam, the Georg-August University of Göttingen, the Centre for International Forestry Research (CIFOR), the International Institute of Tropical Agriculture (IITA), the Centro Internacional de Agricultura Tropical (CIAT), the Indonesian Soils Research Institute (ISRI), the Research Centre for Forest Ecology and Environment (RCFEE) in Vietnam, the Institut de Recherche Agricole pour le Développement (IRAD) in Cameroon, and the Instituto Nacional de Investigacion y Extension Agraria (INIA) in Peru. To ensure relevance at the local level, the project focused on field sites in Indonesia, Vietnam, Cameroon and Peru that are used as part of the Consultative Group on International Agricultural Research's (CGIAR) network of Benchmark Sites for the Alternatives to Slash and Burn (ASB) Partnership for the Tropical Forest Margins.

The project aimed to deliver usable knowledge on critical aspects of international negotiations, national implementation and local experimentation, specifically focusing on integration of forest governance across scales, potential policy instruments in relation to the drivers of deforestation, 
evaluation of these instruments at the local level using modelling approaches, quantification of the impacts of land use change on carbon stocks and greenhouse gas (GHG) emissions, and developing negotiation support tools for use by stakeholders. While the international REDD+ discussions have been a moving target, with both direction and speed of movement not predictable at the project planning stage, these areas of learning have indeed all proved to be important.

Several of the studies carried out under the REDD-ALERT project report their findings in other articles in this Special Issue, and many important publications derived from the project have been published elsewhere. In this synthesis paper, we try to draw these together and reflect on the progress made in the project on understanding how to integrate forest governance across scales, designing and evaluating potential policy instruments for addressing REDD + , improving the measurement and monitoring of carbon stocks and GHG emissions, and communicating these results to REDD+ stakeholders.

\section{Results}

\subsection{Integrating forest governance across scales}

We begin by considering forest governance at the global level and how this might be linked to forest management at the local level. The first issue to address is the multiple perceptions and definitions of what the term forest refers to, as ecosystem, as institution for controlling access and use, and as policy domain in the various contexts in which it is used (van Noordwijk et al. 2014a, this issue). Multiple changes and conversions are possible within the overall forest category, interacting with changes to non-forest categories, described by the term deforestation. Current global forest governance is fragmented in that it contains more than 20 different actors, including both organisations and agreements (Haug and Gupta 2013). Many of these focus on some particular ecosystem service of forests (e.g. the United Nations Framework Convention on Biological Diversity) rather than forests per se, and hence have different goals, mandates, and memberships. As such, while they are able to promote the adoption of concepts (e.g. sustainable forest management) or rules (e.g. trade in sustainably produced wood), they are not able to deal adequately with the major global underlying drivers of deforestation such as the global or national demand for forest and non-forest products, including land (land grabbing has become a serious challenge in recent years), food, biofuels, and other non-timber forest products.

REDD + is the latest effort in forest governance, promoted since 2005 in the context of the emission reduction negotiations (Stern 2007; Eliasch 2008) as a win-win for both forests and climate. It differs from other initiatives in that there will be finance available to compensate countries if they are able to reduce their deforestation and forest degradation rates, although nothing substantial is available yet for actual REDD+ implementation beyond the 'readiness' efforts. REDD+ resources, if indeed benefitting local communities in alternative livelihood scenarios, may help to deal with some of the proximate drivers of deforestation, but that alone is also unlikely to address the underlying drivers of deforestation such as demographic change, national economic and agricultural policy, and global demand for timber, agricultural and forest products.

Using the politics-of-scale approach, Gupta et al. (2013c) argued that countries have multiple reasons to scale up or scale down forest governance issues, and made the case for glocal forest governance - a process by which global through to local issues, trends, drivers and instruments are given due attention and an iterative multi-level governance framework tailored for local relevance is developed for sustainable long-term policy that goes beyond REDD +. Essentially, this approach recognises that forests are part of a global ecosystem (e.g. in terms of regulating atmospheric processes and acting as carbon sinks), but at the same time 
that they are also providers of resources to local economies, which in turn may contribute to, and depend on, the global economy. Thus, glocal forest governance can result in a win-win situation if all actors at the multiple levels of governance gain from the process of participation in the new forest regime. General principles in designing such a governance system should be ensuring links between the policy instrument and the drivers it targets, promoting horizontal and vertical coherence in policy instruments, and developing conflict resolution mechanisms for when these decision-making processes do not align.

Understanding the motivations and concerns of national governments is important in designing effective REDD+ policies, as they sit midway between the global and local ends of the spectrum. While making forestry issues global in nature increases the risk of losing some control of their own resources, the benefits of doing so by a national government include the potential political rewards of being seen to be contributing to a global issue, giving greater weight to domestic policies aimed at sustainable uses of resources where these might not be popular internally, or to promote extra-territorial interests (e.g. in relation to neighbours) to ensure a level playing field. Conversely, the motivations of a national government in making forestry issues local in nature include maintaining sovereignty over resources, better targeting of domestic policies to take into account a range of issues besides just forestry, enhancing buyin by local stakeholders, and avoiding liability for externalised effects (Gupta 2012). Where forests have in the past been seen primarily as a source of government revenue based on use and conversion, motivations for a national government to engage with emission reduction may now include being seen as a responsible member of the global community, and, in doing so, protecting its exports (van Noordwijk et al. 2014a).

Arguments for scaling up and down forest governance have been used opportunistically by countries over time (Gupta 2008). For example, although Canada and the US favoured global forest governance in 1992, the US subsequently reversed this view as a result of pressure from the American Forest and Paper Association who opposed this (Humphreys 2006); at the same time Canada felt that harmonizing global standards would lead to a level playing field and help in exports. While India and Brazil continued to oppose global forest governance until REDD+ came on to the agenda, Malaysia changed its position after 1992.

\subsection{Potential policy instruments}

With an awareness of the complexities of multi-scale governance, Gupta et al. (2013b) then analysed existing policy instruments, classifying them as being regulatory, economic and market-based, suasive, and management measures. Regulatory instruments are those that place restrictions or obligations on the allowable behaviour or choices that organisations or individuals may make, usually through legislation, and include trade restrictions, standards and property rights. Decentralisation, spatial zoning (protected areas), concessions and permits, land access rights, monitoring and surveillance, reporting, and improving law enforcement all fall into this category. Economic instruments can be used to alter the balance between the net returns from different land use options available (equivalent to the opportunity costs of not choosing them). These include import and export tariffs, international funds, grants and loans, taxes and subsidies, carbon offset funds, payments for ecosystem services, micro-credit, debtfor-nature swaps, corporate social responsibility (CSR), ecotourism, and certification schemes. They can be generic within a national economy, such as tariffs, or location-specific, such as PES schemes. Suasive instruments are those that aim to convince actors to change their behaviour other than through economic approaches, while management measures refer to voluntary management by forest dwellers alone or in collaboration with other actors (e.g. nongovernmental organizations, local municipalities), and include community based forest 
management $(\mathrm{CBM})$ and forests that are managed by non-governmental organizations (Edmunds and Wollenberg 2003).

These instruments and measures were then matched to different deforestation and forest conversion drivers at different scales (Gupta et al. 2013b). Most of the available policy instruments tended to focus on local and proximate drivers, some addressed institutional drivers, but there were no instruments that address global underlying (e.g. world demand) and national underlying drivers (e.g. population growth, the perceived need for economic growth). The nature of the underlying drivers (e.g. demographic, economic, technological, political or cultural trends) is that they are often slow processes operating at national or global levels resulting from the aggregated behaviour of many regional, national, subnational and, in some cases, individual entities, referred to in the Panarchy literature as slow variables (Gunderson and Holling 2001). At local level, these slow variables can lead to rapid change, e.g. where migrant flows into a forest margin change a landscape (Galudra et al. 2014, this issue). However, effecting change in these slow variables is either difficult due to their inertia, or unpredictable due to chance interactions with faster changing lower scale variables, and may therefore be beyond the power of any one of these entities to address. Collective action at the global level is clearly required, but there are often conflicting national interests (usually economic) that weaken the international resolve to find solutions to global environmental problems.

To design effective policies to implement REDD+ interventions at the other end of the scale, it is essential to understand the complexity of the specific land use change dynamics that are leading to forest conversion in a given region. A significant part of the REDD-ALERT project aimed at understanding the environmental, social and economic drivers of land use change in tropical forest margins, based on study areas in four countries, Cameroon, Peru, Indonesia and Vietnam, located along a gradient of the ratio rate of deforestation/rate of reforestation and on comparative analyses.

In Vietnam, Meyfroidt et al. (2013b) used remote sensing to analyse land use and cover changes and deforestation trajectories in the coffee-growing area in Dak Lak and Dak Nong provinces over 2000-2010. Land use changes and their links with deforestation and socioeconomic dynamics were analysed with secondary statistics and spatial modelling. Gross and net deforestation rates reached respectively $-0.50 \% \mathrm{y}^{-1}$ and $-0.33 \% \mathrm{y}^{-1}$ of the total area between 2005 and 2010, including humid forests only. Deforestation and degradation were mainly caused directly by shifting cultivation for annual crops, but this was partly driven indirectly by expansion of coffee (Coffea arabica, Coffea canephora) and other perennial crops over agricultural lands. Displacement of shifting cultivation into the forest margins, driven by market crops expansion, was the spatial manifestation of the marginalization of local ethnic minorities and poor migrants, pushed by capital-endowed Kinh and other migrants. Colonization and agricultural expansion in the Central Highlands likely facilitated the reforestation occurring elsewhere in Vietnam, although this increase in net forest area was found to coincide with a continued loss of forest carbon stock, as densely stocked forest continued to be lost and the forest gained had much lower carbon stocks - the latter could therefore be considered degraded forest in REDD+ accounting terms (Meyfroidt and Lambin 2008; Meyfroidt et al. 2013b).

Over the late 2000s, the increasing rate of this deforestation was strongly reducing the benefits of forest recovery, potentially shifting the country back to net losses of natural forest. In that region, policies that may have an impact on reducing deforestation are those that would (a) promote inclusion of the ethnic minorities into the socio-economic, political and agricultural markets spheres, (b) intensify staple crops, (c) strengthen and clarify land use zoning to preserve the remaining forests of value, and (d) identify forested land with the lowest trade-offs 
between environmental services and agricultural potential. In another study, in four villages in the Northern mountains of Vietnam, feedbacks from local environmental degradation on land uses of land managers, the conditions under which such feedbacks occur, and their possible roles in the forest transition were analysed (Meyfroidt 2013). These case studies showed how, under certain conditions, dramatic events or progressively increasing scarcity can modify the perception, interpretation and evaluation of changes in forests by local land managers, and this in turn affects land use practices. Transitions in forest area, density and turn arounds in the satisfaction and livelihoods of local actors are linked, but these three dimensions can evolve in different directions.

In Cameroon, results of remote sensing data analyses in the study area of 1.8 Mha (excluding clouds) showed that, in 2007, forest covered 1.57 Mha, i.e. $83.7 \%$ of the surveyed area. Forests were mostly dense high stands $(64.7 \%)$ whereas degraded forest, covering $19 \%$ of the surveyed land, was found in areas close to settlements and transport axes. Deforestation reached gross and net rates of respectively $-0.85 \% \mathrm{y}^{-1}$ and $-0.24 \% \mathrm{y}^{-1}$ of the total area over the period 2001-2007. This deforestation was almost entirely concentrated in the nonpermanent forest estate (NPFE), with degradation hotspots close to roads and some towns, and reflected mostly the conversion of natural forest into fine-grained shifting cultivation land use mosaics. Gross rates of degradation of high dense forest stands reached $-1.48 \% \mathrm{y}^{-1}$ of the total area, due most probably to logging and forest thinning for forest-farms preparation. A second study assessed the effectiveness of the forest and land zoning policy by determining forest cover changes between 2002 and 2010 in a study area located in the Eastern region, which contains most of the types of units defined by the land zoning plan (Bruggeman et al. 2014). Results show that deforestation rates in most units of the permanent forest estate (PFE) were lower than outside these units, controlling for co-variables through a pair-matching method. A net reforestation is even observed for the entire estate. Yet, significant disparities exist between land zoning units, as deficiencies in the forest legislation and lack of enforcement by the State make the effectiveness of the land use zoning highly dependent on the willingness and capacity of logging companies and local authorities to prohibit agriculture practices. No leakage was detected. These results were confirmed by the community surveys, and show that forest production units as implemented through a land use zoning policy can be an effective tool to control deforestation in Central Africa. A third study showed that, without intervention and if present intensification trends continue, the potential of fallow vegetation to contribute to biodiversity conservation will decline because of a reduced capacity (a) to recover forest vegetation with anything like its original species composition, (b) to connect less disturbed forest patches for forest dependent organisms (Robiglio and Sinclair 2011). Strategies to combat biodiversity loss, including promotion of agroforestry practices and the increase of old secondary forest cover, will need not only to operate at a landscape scale but also to be spatially explicit, reflecting the spatial pattern of species reservoirs and dispersal strategies and human usage across landscapes. Finally, a fourth study, based on data of volumes marketed in urban centres, harvesting operations and on-farm timber management, showed that, with current agricultural expansion and intensification trends associated with small-scale logging, timber resources on rural land are at risk of depletion with direct consequences for domestic timber supply and the thousands of livelihoods it sustains (Robiglio et al. 2013).

In Peru, most deforestation is driven by agricultural expansion (von Blücher et al. 2013). Development of roads into the Amazon forest and connecting rivers to urban markets is followed by migration into the area, mainly from the Andean highlands because of impoverishment and demand for coca (Erythroxylum coca, Erythroxylum novogranatense). These migrants practise slash-and-burn agriculture with very low capital investments, which is followed by a shift to commodity production, and finally production of cash crops and 
livestock for national markets. Since the 1980s, land, capital and labour have been concentrated on coca production due to its high profitability (Matthews et al. 2010).

Policies and instruments aimed at reducing deforestation already exist in Peru (von Blücher et al. 2013). Regional governments have local policy-making powers provided they are consistent with national law, and they also direct the Bureau of Forest and Wildlife offices, although most regional governments are still financially dependent on the national government. In some areas, this decentralisation has led to the establishment of forest management committees drawing together stakeholders at the local level, such as farmers, indigenous people and loggers, but these do not always have the necessary competencies for effective forest management. Spatial planning exists, and all land use change must have authorization. However, agricultural expansion has priority over forestry, and when zoning plans are developed, they are not always enforced. Forest areas are categorised into six different types ranging from protected areas through to permanent production; the former are considered to be successful in preventing deforestation within their borders, although this is mainly because they are in remote areas anyway. Logging concessions have helped to reduce deforestation in many places, but they have not in others due to access roads encouraging agricultural expansion by migrants. Land titling for agricultural land is becoming more common, but to gain titles, it often has to be cleared first, thereby increasing deforestation. In summary, most current policies and instruments aimed at reducing deforestation, while well-meaning, are undermined by the overarching national policy of agricultural expansion. If REDD+ is to be successful, there is a need for a coherent national land use strategy targeted at deforestation drivers, with REDD+ funding used to support and strengthen these existing policies (von Blücher et al. 2013).

In Indonesia, deforestation tends to be a step-wise process of loss of natural forest cover, usually starting with logging concessions that do not deliver on the promise of sustainable forest management but open up areas to migrants, further logging, and conversion to largescale plantations of tree crops or industrial timber estates. Depending on where the operational definition of forest draws the line, the net rate of deforestation in Indonesia has consistently been around $4 \%$ per year (if intact natural forest is the criterion) or shifted to $-0.5 \%$ if a broader forest definition is used (van Noordwijk et al. 2014a, this issue). Specific case studies on Sumatra highlighted the complex interactions between government, private sector, local communities and migrants in forest cover change (Galudra et al. 2014; Mulia et al. 2014, this issue) and the additional complexity resulting from the shifting priorities of government agencies demonstrated that the establishment of protected areas can increase forest conversion in a surrounding zone of at least $10 \mathrm{~km}$, more than what is usually considered as the likely area for leakage effects. Over the past decade conversion from rubber agroforest to monocultural systems, driven by high rubber prices on international markets, has become a major part of the ongoing loss of forest functions, including carbon storage (Villamor et al. 2014).

These country case studies highlight the high contextual variability in causes of deforestation and land use changes. This calls for tailoring the general policy instruments described above to specific contexts, rather than applying one-size-fits-all approaches. It is important to see REDD+ as part of larger systems which also include arable agriculture, grasslands, wetlands, and human settlements, as these can often be a driver of deforestation, particularly agriculture, or may represent possibilities for leakage as well as synergies (e.g. through alternative income opportunities) (Kuik 2014). Dealing with any one land use component (such as forests) in isolation is likely to result in partial solutions at best as the Law of Unintended Consequences starts to operate.

Most policy instruments identified above are already being implemented in these countries; however, the emphasis is on regulatory instruments (spatial planning, land tenure, concessions) 
and economic instruments (taxes and subsidies) and not on suasive instruments that might be able to create broad-based awareness by local stakeholders. Although the four case study countries are large and have massive forest resources, their governance systems range from a socialist-oriented market economy with a communist regime (Vietnam) through transitioning democracies (Indonesia and Peru), to poorer and more unstable economies (Cameroon). A key common feature is the drive to develop rapidly and to optimize national resource use (land, forests, minerals and water) profitably, although the focus of this varies - in Vietnam and Indonesia the focus is on commercial crops bringing easy profit to powerful stakeholders and contributing to the national economy, in Peru, agriculture clearly takes precedence over forests in terms of land-use strategy, and in Cameroon, mining is becoming more lucrative.

\subsection{Evaluating local REDD+ instruments}

To evaluate the effectiveness of various policy instruments at the local level, we used agentbased modelling (ABM) approaches to investigate how local actors, such as subsistence households, firms, companies or local government institutions, may respond to various REDD + policy instruments, including taxes, incentives, regulations, and provision of alternative employment. ABM has the ability to model individual decision-making entities and their interactions, to incorporate social processes and non-monetary influences on decision-making, to conceptually reproduce non-linearities (tipping points) often observed in space-time processes of innovation and change, and to dynamically link social and environmental processes. Decision-making rules for the agents in terms of land use choices were developed from the econometric data and stakeholder information collected in surveys.

Purnomo et al. (2013) used such a model to understand the role of carbon credit price and collective action on REDD+ in a general provincial landscape in Indonesia with a forest core, forest margin, and agricultural mosaic with various actors i.e. local government, service providers, buyers, designated national authority (DNA), national government, and international supervisory body. Issues pursued were related to the effect of carbon prices, brokering, actors' altruism and institutional arrangements on the effectiveness, efficiency and equity of the reduction of carbon emissions. With all actors driven only by self-interest and economic rationality to maximize their benefits from the resources they exploit and manage, the model showed that carbon stocks would be increased in the landscape only if the global price of carbon was more than $\$ 25 \mathrm{tCO}_{2} \mathrm{e}^{-1}$. However, when agents were influenced by an environmental awareness campaign appealing to their altruism, this threshold was lowered to a carbon price of $\$ 15 \mathrm{tCO}_{2} \mathrm{e}^{-1}$. A related more local $\mathrm{ABM}$ focused on understanding farmer decision making in forest margin villages and was combined with role-play games to analyse the response of villagers to agents offering incentives for conversion or conservation (Villamor and van Noordwijk 2011; Villamor et al. 2014).

Similarly, Dyer et al. (2012) used an ABM in a Latin American context to explore the implications of a simple Payment for Ecosystem Services (PES) programme and three variations designed to address its shortcomings, under four scenarios. The model represented 49 households interacting with each other within the local economy of a farming community in a developing area. Each household was modelled as an independent decision maker that engaged in various economic activities, including on-farm activities and wage labour. Households interacted through the exchange of labour and through trade in local maize markets. A key factor was land ownership, which distinguished landholders from the landless - almost $20 \%$ of rented land was supplied by local landlords, the rest being rented out by absentee landowners who owned $30 \%$ of the land in the locality. The results showed that there was a complex relationship between the 3 Es (effectiveness, efficiency and equity) not evident in 
more aggregate analyses. For example, landowners could benefit by enrolling local land into a REDD+ program but local subsistence demands would raise their opportunity costs, while the rent and wage changes created net costs for most private stakeholders. Increasing $\mathrm{C}$ prices reduced the programme's efficiency without solving its inequities, while expanding the programme reduced inefficiencies but increased private costs with only minor improvements in equity. The conclusion from this work was that REDD+ mechanisms should avoid general formulas by giving local authorities the necessary flexibility to address the trade-offs involved (Dyer et al. 2012).

\subsection{Quantifying the impacts}

Where REDD+ incentives are to be performance based, the accounting schemes for GHG emissions and shift from global defaults to locally based emission factors is an important part of the scheme (van Noordwijk et al. 2012). A deeper understanding of the processes underlying emissions is needed to interpret and gain acceptance of emission factors used (van Noordwijk et al. 2014b).

\subsubsection{Above-ground carbon stocks}

It became apparent early in the project that the definition of a forest was a major impediment to accurately estimating GHG emissions from land use changes. National land use designations often split land cover into forest and non-forest categories, although the former may not even contain trees if they have been felled with the intention to replant, and the latter may have trees in the case of agroforestry. Other stakeholders can have different operational forest conceptsranging from the interest in untouched old-growth forest of strict conservation agents, to the very broad United Nations Food and Agriculture Organziation (FAO) definition of minimum size, potential to reach a minimum tree cover, and clarification of what is meant by tree. Without clarification of the forest concept that is to be used in REDD+, there is too much scope for choosing an operational definition that suits a particular point of view (van Noordwijk et al. 2014a). This highlights the importance of using land cover classifications that include a range of systems with accurate estimates of carbon stocks in each.

There are, however, optimal spatial and thematic resolutions in terms of minimising overall uncertainty — as the number of land use/cover classifications used increases, and hence more accurate estimates of the carbon stocks of each classification are used, the errors in assigning pixels to each classification also increase. Typically, spatial aggregation across pixels reduces the random element in the error, while not reducing any bias that might be there. For REDD+ applications we found that aggregating up to a $1 \mathrm{~km}^{2}$ scale reduced uncertainty in areal carbon stock change to below $5 \%$, while estimates for smaller pixel sizes may have a higher chance of containing error (Lusiana et al. 2014, this issue).

\subsubsection{Soil carbon stocks and GHG emissions}

Significant progress was made in the project in the understanding and quantification of $\mathrm{C}$ and GHG fluxes following land use change in the tropics, contributing to narrower confidence intervals on peat-based emissions and their reporting standards, summarised by van Noordwijk et al. (this issue) in the context of peatland conversion in Indonesia.

Several results confirmed the substantial GHG emissions following conversion of undisturbed peat forests into plantations or agriculture. Even though draining peatlands may result in a decrease in $\mathrm{CH}_{4}$ emissions, this is more than offset by the huge increase in 
carbon dioxide $\left(\mathrm{CO}_{2}\right)$ emissions (Hergoualc'h and Verchot 2012). Persch et al. (in preparation) measured aboveground carbon stocks in a primary peat swamp forest, a logged drained forest, and a 7-year-old oil palm plantation at 218, 113 and $29 \mathrm{Mg} \mathrm{ha}^{-1}$, while Comeau et al. (2013) found that $\mathrm{CO}_{2}$ emissions were twice as high in oil palm plantations compared to intact peat swamp forest and transitional logged drained forest. Husnain et al. (this issue) found that spatial variability in $\mathrm{CO}_{2}$ emissions was greater than any differences between land uses on drained peat - bare land, secondary forest and oil palm, Acacia and rubber plantations. In the review of Hergoualc'h \& Verchot (this issue), intact peat swamp forest had the lowest net global warming potential (GWP) at near zero, whereas all other land uses (degraded forest, mixed croplands and shrublands, rice fields, oil palm, Acacia crassicarpa and sago palm plantations) all had considerable positive values, particularly the Acacia. These REDD-ALERT results contributed to a revision by the IPCC in 2013 of the measurement methods for wetlands.

Much of the work focused on gaining a better understanding of the processes leading to these GHG emissions and changes in C stocks. Farmer et al. (2011) discussed the factors involved in GHG emissions from tropical peatlands and reviewed a number of existing models for their suitability for these systems. Important factors included hydrology (i.e. water table depth), temperature, litter quality, microbial community structure, redox potential, disturbance, ebullition, plant mediated transport, dissolved organic carbon, and spatial extent. None of the models they reviewed took all these factors into account, in many cases because inadequate knowledge and data was available.

Subsequent field work aimed at filling in some of these gaps. Marwanto \& Agus (this issue) looked at soil moisture content and air temperature as potential controlling factors of $\mathrm{CO}_{2}$ fluxes using flux chambers in oil palm plantations. Although emissions did track diurnal temperature patterns and decrease with distance from nearby drainage canals, there was no significant relationship between $\mathrm{CO}_{2}$ flux rates and these two variables across all measurements, suggesting there are other factors influencing flux rates besides temperature and soil water content. Husen et al. (this issue) investigated water table depth and the impact of applications of laterite rich in aluminium and iron oxides, which had been suggested for use as an additive to improve peat soil fertility, on $\mathrm{CO}_{2}$ emissions. They found a weak correlation between emission and water table depth, and that laterite applications actually increased emissions and therefore cannot be recommended to control them. Dariah et al. (this issue) tried to separate the soil $\mathrm{CO}_{2}$ emissions derived from fresh plant organic material and that from soil organic material. The distinction is important, as decomposition of fresh plant organic material (e.g. root exudates, dead roots and aboveground litterfall) returns $\mathrm{CO}_{2}$ recently fixed by photosynthesis back to the atmosphere and is essentially carbon-neutral, whereas emissions derived from soil organic matter release carbon that has been stored in the soil for a significant time and therefore represent a net addition to the atmosphere. Total soil $\mathrm{CO}_{2}$ emission measurements need to be adjusted to take this distinction into account. Better insights into the role of roots were also obtained - the study by Dariah et al. (this issue) measured soil $\mathrm{CO}_{2}$ emissions at different distances from the trees in an oil palm plantation and related this to root density, which could have implications for plantation management to reduce emissions. Similarly, work by Persch et al. (in preparation) indicated that roots as a proportion of total biomass increased from undisturbed peat forest through to oil palm plantations.

Farmer et al. (this issue) incorporated much of this information into the Tropical Peatland Plantation-Carbon Assessment Tool (TROPP-CAT) model of soil carbon losses and $\mathrm{CO}_{2}$ emissions following land use change from primary forest on peatlands into plantations, and used this to estimate the impact on emissions of changes in peatland management.

A debate emerged as to the validity of using water table depth to estimate GHG emissions from peatlands, discussed more fully in van Noordwijk et al. (this issue). Previous work 
(outside the project) had shown a good relationship between these variables at the landscape level (Couwenberg and Hooijer 2013). At the field scale, however, Hergoualc'h \& Verchot (this issue) only found a relationship between water table depth and soil $\mathrm{CO}_{2}$ emissions in the croplands and shrublands category and not the other land uses that they examined, and that the slope of the relationship was only about half of that found previously. Some of the current field work has shown that this relationship is not strong (Marwanto and Agus 2014). Van Noordwijk et al. (this issue) discuss a number of possible reasons for this, but clearly there is a need for further work and modelling in this area. This can have important practical applications, as appropriate peatland and plantation management (e.g. controlled water table depths) may help to significantly reduce GHG emissions without necessarily decreasing yields.

For mineral soils, a meta-analysis (Powers et al. 2011) showed that for three land-use transitions with sufficient observations, both the direction and magnitude of changes in the soil $\mathrm{C}$ pool was a function of mean annual precipitation and the dominant soil mineralogy. Additionally, the analysis also highlighted a strong geographic bias in the literature published, where the distribution of field observations was skewed toward regions with higher precipitation and allophanic clay mineralogy (i.e. areas of higher soil fertility and agricultural potential), while areas with low precipitation and high activity clays were clearly underrepresented. It was also found that measurement of soil carbon stocks down to one metre was sufficient to capture changes following land use change.

Other work on mineral soils, which is still in the process of being published, investigated soil nitrous oxide $\left(\mathrm{N}_{2} \mathrm{O}\right)$ and nitric oxide $(\mathrm{NO})$ fluxes. Results from a meta-analysis indicated that overall soil $\mathrm{N}_{2} \mathrm{O}$ and $\mathrm{NO}$ fluxes after land use change in a number of studies in the subtropics were respectively 10 and $110 \%$ higher than before, with conversion from intact forest to agriculture and agroforestry displaying the largest differences (van Lent et al. 2014), which were related to increased soil nitrogen availability, water-filled pore space, and soil acidity.

\subsection{Stakeholder engagement}

Emission reduction primarily requires a shift in development trajectory for tropical forest margins, dealing with multiple actors, multiple incentives and multiple knowledge types. A significant activity of the project was direct engagement of international, national and local stakeholders in the emerging mechanisms of REDD+ to synthesize their perspectives and explore with them how the various REDD+ mechanisms (combining positive and negative incentives) could work out in practice. Role-play versions of process-based simulation models allowed for active engagement with 'agents of change' that provide incentives to increase or decrease emissions.

Use of the Q-method indicated a consensus among expert stakeholders on the necessity of tackling climate change through forestry in the tropics, increasing the value of standing forests (including its biodiversity), and promoting sustainable forest management (Nijnik et al. 2014, this issue). However, there was a diversity of views on REDD+ itself, with three out of the four attitudinal groups identified (the Pragmatists, Conventionalists and Optimists), albeit expressing different levels of belief in its effectiveness and acceptability. The fourth group, the Sceptics, however, rejected the majority of objectives and issues related to REDD+, showing their general disbelief in REDD+ programmes. The results also indicated that the potential of REDD/REDD+ is shaped not only by international climate change intervention policy, but to a large extent by national and regional policies and various cultural values that affect the acceptability of REDD+ projects by local people (Nijnik et al. 2011). These results should be of help to decision-makers in preventing and/or resolving the conflicts (e.g. between stakeholder interests), and in designing climate policy measures, as well as in better targeting 
of REDD+ type projects, for them to also provide co-benefits to end-users more effectively, both at a local level and internationally.

In a major review of the literature on payments for ecosystem services, we found that the paradigms of commoditisation, compensation and co-investment need to be disentangled (van Noordwijk et al. 2012). Much of the PES literature describes commoditisation ('carbon markets') as an ideal, but most of the practices that work have a strong co-investment character, where multiple currencies are at play (respect, recognition, rights as well as economic rewards), and risks as well as benefits are shared. Contrary to current perceptions of REDD+ where exchanges of money for emission reduction are to be expressed in the same units from international transactions to farm-level contracts, we found that there is considerable opportunity to combine commoditisation at national borders (performance based economic incentives, with an annual assessment linked to pay-or-no-pay), a compensation paradigm for allocations and performance between sectors and provinces, and a co-investment paradigm with a 20-year perspective on tree-based land uses initiated at the farm level. Such a concept, however, is more likely to derive from a NAMA (Nationally Appropriate Mitigation Actions) perspective across sectors than from a REDD+ one per se, where cross-sectoral leakage is hard to assess and evidence-based pay will be difficult (van Noordwijk et al. 2014a, this issue). The cross-scale exchanges in REDD+ application were found to involve an 'efficiency' (emission reduction versus economic incentives) as well as 'fairness' dimension (recognition and respect versus commitment). Most of the existing discourse underestimates the fairness and nonfinancial exchanges, but success of REDD+ likely depends on getting the paradigms and incentives right at all scales.

\section{Discussion}

The overall aim of the REDD-ALERT project was to evaluate how national-level agreements might be translated into sub-national policies to effect change in land use behaviour to reduce deforestation, and to consider where and when REDD+ might work. It is important to appreciate that existing deforestation drivers and institutional frameworks for governing forests, both for their partial conservation and commercial exploitation are already in place both at the global and national level, and that any REDD+ policy instrument should fit as much as possible into these dynamics and frameworks rather than being applied in isolation. At the global level, it should be consistent with, and build upon, other international policies affecting forests (Gupta et al. 2013c). At the regional level, there will be trading networks in place, which will need to be considered to quantify the leakage of emission reduction when countries that reduce current or repair past forest loss increase their imports or reduce exports, thus shifting emissions across national borders (Atmadja and Verchot 2012). At the national level, as part of the development of an enabling environment through REDD-Readiness activities, such instruments should be integrated into existing forest-related institutions (e.g. von Blücher et al. 2013) rather than distract resources and manpower away from other goals. In Indonesia, for example, REDD+ instruments should be built in to existing concepts of community forests, ecosystem restoration, the moratorium and peat land policy, in addition to the existing zoning of conservation, production and protection forests. The challenge, of course, is how to demonstrate additionality; i.e. how to ensure that the REDD+ instruments are delivering reductions in deforestation that would not have happened through existing mechanisms anyway, particularly if they are similar, and that the REDD + funds do not disappear into general funds (Berry et al. 2013). A business as usual (BAU) scenario would be required, and procedures for tracing specific funds through existing mechanisms put in place, although the 
costs of doing this need to be balanced against the benefits. The onus should be on the receiving country to demonstrate additionality to receive REDD+ funding.

There should also be some balance between effective reduction of deforestation on the one hand, and national development needs on the other, particularly in the definition of historical deforestation reference levels. A recurrent theme is the complexity of local land use change dynamics, so that it is highly unlikely that one REDD+ instrument, or even package of instruments, will fit all; instead, there needs to be a mixture of demand-led and marketbased approaches and regulatory instruments tailored to each situation, involving hybrid coalitions of public and private actors (Lambin et al. 2014). Beyond national territory-based governance of land use, these new instruments can contribute to improved governance of flows ending up and derived from land use, including flows of capital, agricultural or forestry products, or ecosystem services (Sikor et al. 2013).

A second factor for REDD+ to work is that of equity and fairness for all stakeholders involved (van Noordwijk and Leimona 2010; Luttrell et al. 2013). Benefits accruing from a reduction in deforestation need to be shared equitably down the chain from national government to local land users - all need each other (Matthews and Dyer 2011). Intermediate actors are certainly needed to administer schemes and certify that emission reductions have in fact taken place and to 'deliver' these certified reductions to national and international buyers (Luttrell et al. 2013), but if too many funds are appropriated by actors in the upstream part of the chain or they are captured by local elites, then those at ground level will not be incentivised to find alternatives to tree clearing. Disincentivising any of these actors will mean that the whole system will cease to function, but the challenge is to find a way of distributing benefits such that all find it worth their while to contribute. Benefit sharing can be on the basis of legal rights, actual measured emissions reductions, stewardship over low emission sources, costs incurred, facilitation of REDD+ processes, or poverty (Luttrell et al. 2013). A quantitative approach to a fair and efficient benefit distribution might be based on the Shapley algorithm that has been used, for example, for analysing bargaining positions in labour issues by calculating a weighted attribution of the overall outcome of a multi-step and multi-actor process to the difference any actor could make by non-participation (Monderer and Shapley 1996). To operationalize it, one will need an agent-based model that is robust in its description of functions and includes the flexible options of actors to adjust, by replacing functions, to the omission of any specific actor. Current ABM's are not yet designed to carry out such analysis (Matthews and Dyer 2011).

Related to the fairness dimension is the need to ensure that local vulnerable stakeholders are not adversely affected by REDD+ programmes (Peskett 2011). For example, the study of Dyer et al. (2012) indicated that local land rents would increase and wages of the landless would decrease if land was taken out of agricultural production to grow trees. Many poor people are dependent on the forest for their livelihoods (e.g. Vedeld et al. 2004)-safeguards need to be put in place to ensure that they are not denied customary rights of access to food and water (Peskett et al. 2008; Gupta et al. 2013a). Free, prior and informed consent of local communities and individual groups is critical for all planned programs (de Royer et al. 2013). Further, as stressed above, REDD+ interventions need to be integrated within a broader governance framework, so that other interventions can compensate for the potential adverse effects of REDD+.

What is the future for REDD+? In Downs" "issue-attention cycle theory" (Downs 1972), an environmental issue stays on the political agenda for a limited period. In the first pre-problem phase, the problem exists but is not the subject of public discussion. In the second phase, the public is alarmed and constructively aims to deal with the problem thinking that this is possible 'without any fundamental reordering of society itself'. During the third phase, social actors 
become aware of the costs of dealing with the problem. In the last phase, public attention may decline as the problem is seen as too complex or expensive to address, or requiring major structural overhaul of societies. In relation to REDD+, the second phase probably ended in Copenhagen in 2009 where no binding agreement was adopted, and we have now entered the third phase, and although there is still progress being made on REDD + policy making, the magnitude of the challenges to be addressed in designing a workable REDD+ mechanism that takes all ecosystem services into account, and is equitable, is now being recognised. Indeed, the World Bank's Independent Evaluation Group report on the Forest Carbon Partnership Facility (FCPF) declared in 2012 that "REDD+ is a more expensive, complex, and protracted undertaking than was anticipated at the time of the FCPF's launch" (IEG 2011). The question is whether these challenges can be overcome to develop lasting solutions where the benefits outweigh the costs, so that the global community can avoid entering Downs' fourth phase of disillusionment. Will REDD be a short-lived hype or will it succeed in producing lasting change, effectively preserving forest carbon stocks in the tropics and contributing to development and poverty alleviation?

There are indications that there is only a short and relatively small window of opportunity of making REDD+ work. For example, GHG emissions from deforestation and other land use change as a fraction of total global GHG emissions have been decreasing over time due to the increase in fossil fuel emissions; in 1960 it was around $38 \%$ of the total, in 1990 it was around $20 \%$ (Le Quéré et al. 2009), and in 2013 it had dropped to 8 \% (Global Carbon Project 2013). Thus, any gains in reducing forest-related emissions contribute less to overall reductions than previously expected and consequently it will be less likely to attract political interest as a substantive mitigation option.

A second factor has been the realisation of the costs involved, including opportunity costs, setup costs, implementation costs, safeguard costs and monitoring costs, (the last four sometimes being grouped under transaction costs, Rendón Thompson et al. 2013), all resulting in additional complications (Plugge et al. 2013; Rendón Thompson et al. 2013; Phan et al. 2014). Opportunity costs are the costs foregone of alternative land uses (Potvin et al. 2008), and are hostage to the vagaries of international finance and variations in commodity prices (food and biofuels) (Kindermann et al. 2008). Transaction costs, in particular, may be a significant fraction of the total costs (Baker et al. 2010), ranging from US $\$ 0.73 \mathrm{ha}^{-1}$ (Rendón Thompson et al. 2013) in Peru to US\$15 ha ${ }^{-1}$ in Ecuador (Grieg-Gran 2008). Monitoring costs alone have been estimated to be between US\$0 ha ${ }^{-1}$ and US $\$ 4 \mathrm{ha}^{-1}$, depending on project and technology (Rendón Thompson et al. 2013). Stakeholders in Indonesia estimated that transaction costs could be as 35-50\% of the total, depending on whether they were from an NGO, government or research institution, but thought that between 10 and $45 \%$ would be fair (Lusiana et al. 2014).

There is also concern about the stability of the price of carbon credits and their recent downward response to the lack of international political commitment to mitigation, the socalled 'disadvantageous economics' of REDD+ (Sunderlin et al. 2014). Current estimates of the costs required to reduce deforestation to $50 \%$ is around US\$ 12.5 billion per year (Angelsen 2013), but so far only US\$ 6.9 billion has been pledged from public sector sources from 2006 to 2017, representing an average of US\$ 0.53 billion per year. Even less is coming from the voluntary and compliance market sectors-US\$ 0.07 million (2012) and US\$ 0.018 million per year (2012), respectively (Peters-Stanley et al. 2013). This lack of demand for REDD + carbon credits is largely due to the lack of a binding global climate agreement at the UNFCCC level (Sunderlin et al. 2014). Moreover, the market for generating credits is highly skewed towards a few large deforesting countries - Brazil, Indonesia, Myanmar, Congo and Zambia together are responsible for around $60 \%$ (by area) of the world's deforestation. They 
may have economies of scale in generating carbon credits, especially for the costs component beyond opportunity costs, which could bring the price of such credits down to levels at which it is not economic for other smaller countries to consider REDD+ schemes. Indeed, this was one of the reasons that REDD+ credits were excluded from the European Union Emissions Trading System (EU ETS) (Phelps et al. 2011). There is also a feeling of unfairness, in that REDD + is seen in some quarters as a licence allowing industrialised nations to carry on emitting at the same rates, reducing the need for them to do anything apart from passing on the costs of purchasing carbon credits to their consumers (Gupta et al. 2013a). Often too, the public sector funds allocated to REDD+ are not new and are taken from existing aid budgets already being reduced by the recession, thereby reducing the funds available for other development objectives, as well as shifting development assistance funds from definite to conditional (Angelsen 2013).

So what is the future of the world's forests? A number of developing, tropical countries have recently been through a forest transition, thus shifting from shrinking to expanding forests at a national scale (Meyfroidt and Lambin 2011), suggesting that reforestation at least is possible. According to Köthke et al. (2013), 29 developing countries are now reporting increases in forest area. However, we were able to show that restoring forests in one country is generally associated with a significant outsourcing of forest exploitation to neighbouring countries via increased imports of wood and agricultural products (Meyfroidt and Lambin 2010). Regardless of the degree of deforestation present in a country, therefore, for lasting solutions to be developed it is essential to see forests as components of well-established economic and trading networks, as well as of larger systems of land use including arable agriculture, grasslands, wetlands, and human settlements.

Deforestation is only one of several major problems that humans need to grapple with in the next century - together with concomitant increases in demand for food, water and energy against a backdrop of climate change, urbanisation, and limited land resources. Indeed, REDD+ instruments and actors are only one aspect of the ongoing transformation of land use planning in many developing countries, involving multiple (and sometimes conflicting) actors and interests crystallized around the food security/climate change/biodiversity nexus (Rudel and Meyfroidt 2014). These actors typically operate at different scales, and land use in rural regions of the tropics are indeed increasingly influenced by geographically and institutionally distant drivers (Meyfroidt et al. 2013a). Ensuring the long-term effectiveness of REDD+ requires the building of coalitions of multiple stakeholders to formulate general rules to structure land use decisions around these various interests.

If a global forest transition is to occur, therefore, integrated strategies are required (Meyfroidt and Lambin 2011). Technological innovations for increasing production on existing agricultural land, reducing losses in the food chain, and returning nutrients from urban to rural areas may spare forest land by reducing the need to clear more land for agriculture (Fischer et al. 2008; Lindenmayer and Cunningham 2013; Minang et al. 2014), although this may have to be combined with land use zoning to avoid inadvertent incentives for further clearing (Rudel et al. 2009). In this context, a legitimate question is whether REDD + funding might be effectively used for funding agricultural research as a mitigation strategy in its own right (Burney et al. 2010; Matthews and De Pinto 2012). Meyfroidt and Lambin (2011) also argue that changes in consumption patterns are required for any potential global forest transition, especially reduction of wastes and decreasing demand of the most land-demanding productse.g. meat (Meyfroidt and Lambin 2011). Across all these approaches, for the poorest fraction of humanity, the issues of equity, and access and sharing of food and land resources, are crucial to ensure food security (Godfray et al. 2010). These approaches will rely on various tools, including state-level command-and-control, regulatory tools, rural and agricultural 
development policies, and emerging market-based instruments. REDD+ could support most of these strategies, and thus should not be considered only as a program of Payments for Environmental Services for agents of deforestation and forest degradation.

\section{Conclusions}

While REDD+ has not been the overwhelming 'win-win' solution to reducing GHG emissions that was hoped for at the beginning, it should be recognised that it has mobilized global attention and social actors on the need to understand forests and human-forest interactions, and to deal with forests at a global level. The REDD-ALERT project has contributed to the much better understanding that we now have of the drivers of deforestation in different countries and the limits of instruments in dealing with these drivers. This has led to a realization of the need for a systems view to consider all land uses and to mainstream forests into national development, agricultural, energy and mining policies. However, if the resources are not forthcoming, this may lead countries to revert to their original position of seeing forests primarily as a subject of national sovereignty and a source of income. Future efforts should aim to build on the institutional progress made and have it contribute to the emergence of new landscape-based approaches, beyond the REDD+ forest focus, that link the local, national and global dimensions of a green economy with the accountability needed to achieve effective climate policies.

Acknowledgments The authors are grateful for financial support for this work from the European Union under the REDD-ALERT (Reducing Emissions from Deforestation and Degradation from Alternative Land Uses in Rainforests of the Tropics) project, Grant Agreement number 226310. The authors have no other relevant affiliations of financial involvement with any organisation or entity with a financial interest in or financial conflict with the subject matter or materials discussed in the manuscript apart from those disclosed. No writing assistance was utilised in the production of this manuscript.

Open Access This article is distributed under the terms of the Creative Commons Attribution License which permits any use, distribution, and reproduction in any medium, provided the original author(s) and the source are credited.

\section{References}

Angelsen A (2013) REDD+ as performance-based aid: general lessons and bilateral agreements of Norway. WIDER Working Paper No. 2013/135. UNU-WIDER

Atmadja S, Verchot L (2012) A review of the state of research, policies and strategies in addressing leakage from reducing emissions from deforestation and forest degradation (REDD plus). Mitig Adapt Strateg Glob Chang 17:311-336

Baker TR, Jones JPG, Thompson ORR, Cuesta RMR, Castillo DD, Aguilar IC et al (2010) How can ecologists help realise the potential of payments for carbon in tropical forest countries? J Appl Ecol 47:1159-1165

Berry NJ, Harley R, Ryan CM (2013) Enabling communities to benefit from REDD+: pragmatic assessment of carbon benefits. Carbon Manag 4:571-573

Bruggeman D, Meyfroidt P, Lambin EF (2014) Production forests as a conservation tool: Cameroon's land use zoning policy. Land Use Policy. (submitted)

Burney JA, Davis SJ, Lobell DB (2010) Greenhouse gas mitigation by agricultural intensification. Proc Natl Acad Sci U S A 107:12052-12057

Comeau L-P, Hergoualc'h K, Smith JU, Verchot L (2013) Conversion of intact peat swamp forest to oil palm plantation: effects on soil $\mathrm{CO}_{2}$ fluxes in Jambi, Sumatra. Working Paper 110. CIFOR, Bogor, Indonesia

Couwenberg J, Hooijer A (2013) Towards robust subsidence-based soil carbon emission factors for peat soils in south-east Asia, with special reference to oil palm plantations. Mires Peat 12:1-13 
de Royer S, Galudra G, Pradhan U (2013) Assessing and adopting social safeguards in all planned programs (AASSAPP). In: van Noordwijk M, Lusiana B, Leimona B, Dewi S, Wulandari D (eds) Negotiation-support toolkit for learning landscapes. World Agroforestry Centre (ICRAF), Bogor, pp 240-244

Downs A (1972) Up and down with ecology: the "issue-attention cycle". In: The Public Interest. pp 38-50, P.O. Box 810425, Boca Raton, FL 33481

Dyer G, Matthews R, Meyfroidt P (2012) Is there an ideal REDD+ program? A village-wide analysis of policy trade-offs. PLoS ONE 7:e52478

Edmunds E, Wollenberg E (2003) Whose devolution is it anyway? Divergent constructs, interests and capabilities between poorest forest users. In: Edmunds E, Wollenberg E (eds) Local forest management: the impacts of devolution policies. Earthscan, London, pp 150-166

Eliasch J (2008) Climate Change: Financing Global Forests: the Eliasch Review. UK Government Office of Climate Change, London, p 250

Farmer J, Matthews R, Smith JU, Smith P, Singh BK (2011) Assessing existing peatland models for their applicability for modelling greenhouse gas emissions from tropical peat soils. Curr Opin Environ Sustain 3: 339-349

Fischer J, Brosi B, Daily GC, Ehrlich PR, Goldman R, Goldstein J et al (2008) Should agricultural policies encourage land sparing or wildlife-friendly farming? Front Ecol Environ 6:380-385

Galudra G, van Noordwijk M, Agung P, Suyanto S, Pradhan U (2014) Migrants, land markets and carbon emissions in Jambi, Indonesia: land tenure change and the prospect of emission reduction. Mitig Adapt Strateg Glob Chang. (in press)

Global Carbon Project (2013) GCP_Carbon Budget. Vol. 2014, Global Carbon Project

Godfray HCJ, Beddington JR, Crute IR, Haddad L, Lawrence D, Muir JF et al (2010) Food security: the challenge of feeding 9 billion people. Science 327:812-818

Grieg-Gran M (2008) The cost of avoiding deforestation: update of report prepared for the Stern Review of the Economics of Climate Change. International Institute for Environment and Development, London

Gunderson LH, Holling CS (2001) Panarchy. Island Press, Washington DC

Gupta J (2008) Global change: analysing scale and scaling in environmental governance. In: Young OR, Schroeder H, King LA (eds) Institutions and environmental change: principal findings, applications, and research frontiers. MIT Press, Cambridge, pp 225-258

Gupta J (2012) Glocal forest and REDD+ governance: win-win or lose-lose? Curr Opin Environ Sustain 4:1-8

Gupta J, Matthews R, Meyfroidt P, Haug C, Kuik O, van der Grijp N (2013a) The future of forests. In: Gupta J, van der Grijp N, Kuik O (eds) Climate change, forests and REDD: lessons for institutional design. Routledge, London, pp 229-258

Gupta J, Shin HY, Matthews R, Meyfroidt P, Kuik O (2013b) The forest transition, the drivers of deforestation and governance approaches. In: Gupta J, van der Grijp N, Kuik O (eds) Climate change, forests and REDD: lessons for institutional design. Routledge, London, pp 25-51

Gupta J, van der Grijp N, Kuik O (2013c) Climate change, forests and REDD: lessons for institutional design. Routledge, London, p 258

Haug C, Gupta J (2013) Global forest governance. In: Gupta J, van der Grijp N, Kuik O (eds) Climate change, forests and REDD: lessons for institutional design. Routledge, London, pp 52-76

Hergoualc'h KA, Verchot LV (2012) Changes in soil $\mathrm{CH}_{4}$ fluxes from the conversion of tropical peat swamp forests: a meta-analysis. J Integr Environ Sci 9:93-101

Humphreys D (2006) Logjam. Deforestation and the crisis of global governance. Routledge, London, p 328

IEG (2011) The Forest Carbon Partnership Facility: Global Program Review. Vol. 6, Issue 3, World Bank Independent Evaluation Group, Washington DC, p 74

Kindermann G, Obersteiner M, Sohngen B, Sathaye J, Andrasko K, Rametsteiner E et al (2008) Global cost estimates of reducing carbon emissions through avoided deforestation. Proc Natl Acad Sci U S A 105: 10302-10307

Köthke M, Leischner B, Elsasser P (2013) Uniform global deforestation patterns_ — an empirical analysis. For Policy Econ 28:23-37

Kuik O (2014) REDD+ and international leakage via food and timber markets: a CGE analysis. Mitig Adapt Strateg Glob Chang. (in press)

Lambin EF, Meyfroidt P, Rueda X, Blackman A, Börner J, Cerutti PO et al (2014) Effectiveness and synergies of private and public actions for land use governance in tropical regions. Glob Environ Chang (under revision)

Le Quéré C, Raupach MR, Canadell JG, Marland G, Bopp L, Ciais P et al (2009) Trends in the sources and sinks of carbon dioxide. Nat Geosci 2:831-836

Lindenmayer DB, Cunningham SA (2013) Six principles for managing forests as ecologically sustainable ecosystems. Landsc Ecol 28:1099-1110 
Lusiana B, van Noordwijk M, Johana F, Galudra G, Suyanto S, Cadisch G (2014) Implications of uncertainty and scale in carbon emission estimates on locally appropriate designs to reduce emissions from deforestation and degradation (REDD+). Mitig Adapt Strateg Glob Chang. (in press)

Luttrell C, Loft L, Gebara MF, Kweka D, Brockhaus M, Angelsen A et al (2013) Who should benefit from REDD+? Rationales and realities. Ecol Soc 18:52

Marwanto S, Agus F (2014) Is $\mathrm{CO}_{2}$ flux from oil palm plantations on peatland controlled by soil moisture and/or soil and air temperatures? Mitig Adapt Strateg Glob Chang. (in press)

Matthews R, De Pinto A (2012) Should REDD+ fund 'sustainable intensification' as a means of reducing tropical deforestation? Carbon Manag 3:117-120

Matthews R, Dyer G (2011) Evaluating the impacts of REDD+ at sub-national scales: are our frameworks and models good enough? Carbon Manag 2:517-527

Matthews RB, Swallow B, van Noordwijk M, Milne E, Minang P, Bakam I et al (2010) Development and application of methodologies for reduced emissions from deforestation and forest degradation (REDD). pp 188, Macaulay Land Use Research Institute, Aberdeen, UK, and World Agroforestry Centre, Nairobi Kenya

Meyfroidt P (2013) Environmental cognitions, land change, and social-ecological feedbacks: local case studies of forest transition in Vietnam. Hum Ecol 41:367-392

Meyfroidt P, Lambin E (2008) Forest transition in Vietnam and its environmental impacts. Glob Chang Biol 14: 1319-1336

Meyfroidt P, Lambin EF (2010) Forest transition in Vietnam and displacement of deforestation abroad. Proc Natl Acad Sci U S A 106:16139-16144

Meyfroidt P, Lambin EF (2011) Global forest transition: prospects for an end to deforestation. Annu Rev Environ Resour 36:9.1-9.29

Meyfroidt P, Lambin EF, Erb KH, Hertel T (2013a) Globalization of land use: distant drivers of land change and geographic displacement of land use. Curr Opin Environ Sustain 5:438-444

Meyfroidt P, Vu TP, Hoang VA (2013b) Trajectories of deforestation, coffee expansion and displacement of shifting cultivation in the Central Highlands of Vietnam. Glob Environ Chang 23:1187-1198

Minang PA, van Noordwijk M, Kahurani E (2014) Partnership in the tropical forest margins: a 20-year journey in search of alternatives to slash-and-burn. World Agroforestry Centre (ICRAF), Nairobi, p 241

Monderer D, Shapley LS (1996) Fictitious play property for games with identical interests. J Econ Theory 68 : 258-265

Mulia R, Widayati A, Suyanto, Agung P, Zulkarnain MT (2014) Low carbon emission development strategies for Jambi, Indonesia: simulation and trade-off analysis using the FALLOW model. Mitig Adapt Strateg Glob Chang. (in press)

Nijnik M, Miller D, Nijnik A, Fiorini S, Vogt N, Brondizion E et al (2011) Public participation for planning the sustainable use of natural resources and landscape change: methodology development. Int J Interdiscip Soc Sci 5:303-320

Nijnik A, Nijnik M, Bergsma E, Matthews R (2014) Heterogeneity of experts' opinion regarding opportunities and challenges of tackling deforestation in the tropics: a Q methodology application. Mitig Adapt Strateg Glob Chang. (in press)

Peskett L (2011) Benefit sharing in REDD+: exploring the implications for poor and vulnerable people. World Bank and REDD-NET, Washington D.C., p 40

Peskett L, Huberman D, Bowen-Jones E, Edwards G, Brown J (2008) Making REDD work for the poor. Poverty Environment Partnership (PEP), London, p 78

Peters-Stanley M, Gonzalez G, Yin D, Goldstein A, Hamrick K (2013) Covering new ground: state of the forest carbon markets 2013. Forest Trends' Ecosystem Marketplace, Washington D.C., p 80

Phan T-HD, Brouwer R, Davidson M (2014) The economic costs of avoided deforestation in the developing world: a meta-analysis. J For Econ 20:1-16

Phelps J, Webb EL, Koh LP (2011) Risky business: an uncertain future for biodiversity conservation finance through REDD+. Conserv Lett 4:88-94

Plugge D, Baldauf T, Koehl M (2013) The global climate change mitigation strategy REDD: monitoring costs and uncertainties jeopardize economic benefits. Clim Chang 119:247-259

Potvin C, Guay B, Pedroni L (2008) Is reducing emissions from deforestation financially feasible? A Panamanian case study. Clim Pol 8:23-40

Powers JS, Corre MD, Twine TE, Veldkamp E (2011) Geographic bias of field observations of soil carbon stocks with tropical land-use changes precludes spatial extrapolation. Proc Natl Acad Sci U S A 108:6318-6322

Purnomo H, Suyamto D, Irawati RH (2013) Harnessing the climate commons: an agent-based modelling approach to making reducing emission from deforestation and degradation (REDD)+ work. Mitig Adapt Strateg Glob Chang 18:471-489

Rendón Thompson OR, Paavola J, Healey JR, Jones JPG, Baker TR, Torres J (2013) Reducing emissions from deforestation and forest degradation (REDD+): transaction costs of six Peruvian projects. Ecol Soc 18:17 
Robiglio V, Sinclair FL (2011) Maintaining the conservation value of shifting cultivation landscapes requires spatially explicit interventions. Environ Manag 48:289-306

Robiglio V, Lescuyer G, Cerutti PO (2013) From farmers to loggers: the role of shifting cultivation landscapes in timber production in Cameroon. Small-scale For 12:67-85

Rudel TK, Meyfroidt P (2014) Organizing anarchy: the food security-biodiversity-climate crisis and the genesis of rural land use planning in the developing world. Land Use Policy 36:239-247

Rudel TK, Schneider L, Uriarte M, Turner BL II, DeFries R, Lawrence D et al (2009) Agricultural intensification and changes in cultivated areas, 1970-2005. Proc Natl Acad Sci U S A 106:20675-20680

Sikor T, Auld G, Bebbington AJ, Benjaminsen TA, Gentry BS, Hunsberger C et al (2013) Global land governance: from territory to flow? Curr Opin Environ Sustain 5:522-527

Stern N (2007) The Economics of Climate Change: the Stern Review. Cambridge University Press, Cambridge, p 692

Sunderlin WD, Ekaputri AD, Sills EO, Duchelle AE, Kweka D, Diprose R et al (2014) The challenge of establishing REDD+ on the ground: insights from 23 subnational initiatives in six countries. Occasional Paper 104. pp 44, CIFOR, Bogor, Indonesia

van Lent J, Hergoualc'h K, Verchot LV (2014) Soil $\mathrm{N}_{2} \mathrm{O}$ and $\mathrm{NO}$ emissions from land use and land-use change in the tropics and subtropics: a meta-analysis. Glob Chang Biol (submitted)

van Noordwijk M, Leimona B (2010) Principles for fairness and efficiency in enhancing environmental services in Asia: payments, compensation, or co-investment? Ecol Soc 15:17, [online] URL: http://www. ecologyandsociety.org/vol5/iss4/art/

van Noordwijk M, Leimona B, Jindal R, Villamor GB, Vardhan M, Namirembe S et al (2012) Payments for environmental services: evolution toward efficient and fair incentives for multifunctional landscapes. Annu Rev Environ Resour 37:389-420

van Noordwijk M, Agus F, Dewi S, Purnomo H (2014a) Reducing emissions from land use in Indonesia: motivation, policy instruments and expected funding streams. Mitig Adapt Strateg Glob Chang. (in press)

van Noordwijk M, Matthews R, Agus F, Farmer J, Verchot L, Hergoualc'h K et al (2014b) Mud, muddle and models in the knowledge value chain to action on tropical peatland issues. Mitig Adapt Strateg Glob Chang. (in press)

Vedeld P, Angelsen A, Sjaastad E, Berg GK (2004) Counting on the environment: forest incomes and the rural poor. In: Environment Economics Series Paper 98. pp 95, World Bank, Washington, DC

Villamor GB, van Noordwijk M (2011) Social role play games versus individual perceptions of conservation and PES agreements for maintaining rubber agroforests in Jambi (Sumatra), Indonesia. Ecol Soc 16:27

Villamor GB, Pontius RG, van Noordwijk M (2014) Agroforest's growing role in reducing carbon losses from Jambi (Sumatra), Indonesia. Reg Environ Chang 14:825-834

von Blücher F, van der Grijp N, Gupta J, Santa Maria P (2013) Case study: Peru. In: Gupta J, van der Grijp N, Kuik O (eds) Climate change, forests and REDD: lessons for institutional design. Routledge, London, pp $163-184$ 